\title{
A Six Dimensional Model for Understanding the Stress faced by Health Care Professionals working in Visakhapatnam
}

\author{
M.Satyavathi ${ }^{1}$, Dr. P. Vijaya Kumar ${ }^{2}$ \\ ${ }^{1}$ Research Scholar, School of Management Studies, J.N.T.University Kakinada, AP, India \\ ${ }^{2}$ Director, School of Management Studies, J.N.T.University Kakinada, AP, India
}

\begin{abstract}
It is a known fact that stress is detrimental to the performance of an employee or an organization. The mere acknowledgement of the presence of stress is not sufficient, rather it becomes imperative that organizations study the causative factors of stress and then arrive at mechanisms which can reduce stress. This also indirectly means that stress cannot be totally eliminated as a certain amount of stress is beneficial in motivating the individual to increase performance to acceptable levels. Now there exists a tradeoff between acceptable levels of stress and acceptable levels of performance. The present paper aims to identify these causative factors and then follow a dimensional approach to representation of stress in medical health professionals in Visakhapatnam.
\end{abstract}

Keywords: Stress, Performance, Work, Work Life Balance.

\section{Introduction}

The main aim of the paper is to understand the stress faced by the medical health professionals working in the region surrounding Visakhapatnam. As previous studies have indicated the main cause of this stress seems to be the work life imbalance. An attempt is being made in this paper to understand the causative factors of this stress and to be able to relate this stress to the 8-dimensional model being suggested. Once these causative factors have been studied and their relative importance in being able to cause analyzed, the paper aims to parameterize these factors so that a mathematical model be suggested. This mathematical model can be used as a reference against the previous case studies of stress which have been carried out. Once this comparative study has been done, additional factors which might have been missed out may be factored in and the model be modified in order to overcome the discrepancy. Thus we aim to prepare a comprehensive model which is able to identify the stress that may exist within an organization. For this purpose, the assumptions and simplifications which are being considered are being provided at the beginning of the paper. Then a step by step methodology is being suggested which may result in the identification of stress. Once this model has been validated, additional studies can then be carried out to study the ways and means in which the various factors may be modified to reduce the stress. Another perspective from the managerial point of view would be to suggest the ways and means in which different organizations are able to adopt this model into their human resource practices so that productivity of the organization is either increased or maintained. While this paper aims to understand stress in terms of eight dimensions, it also acts as a beginning point to enhance it further qualitatively to the individual that it stops from being an impediment to organizational growth.

\section{Review Literature}

The interconnectedness of employees and the environment in which they work has been studied in Sue Campbell Clark, (2010). This led us to understand the important role played by the working environment in either causing or reducing stress and there by Work-Life balance. The non-mutual exclusiveness and strong interdependencies between the personal and professional lives of nurses has been studied in Wise (2003). This helped us to gain an understanding of the professional challenges faced by the nurses and the manner in which their personal lives may impact or be impacted by their professional lives.

The impact of inappropriate occupational timings on stress has been discussed in Jan Ole RØVIK (2007). This led us to understand the important role played by occupational timings in causing stress. The impact of flexible working hours on work life balance has been studied in Obstet Gynecol, (2007) and Phil J.M. Heiligersa, b, (2000). Beauregard and Henry (2009) discuss the current practices being followed by organizations to achieve Work -Life Balance. From here we were able to have a general understanding of the various alternatives which organizations have in terms of overcoming stress. The importance of family in achieving Work-Life balance has been discussed in Frame and Hartog, (2003). This caused us to consider the time spent with the famiy members as an important component in trying to understand stress. 


\section{Six Dimensional Approach}

The various factors which affect and are effected by stress have been grouped into 6 dimensions. By organizing these aspects into dimensions, it becomes easy to study the impact that these factors have on the stress caused to the employees.

3.1 Growth: It deals with the feedback that is associated with being able to utilize his/her abilities in order to provide personal and professional satisfaction.

3.2 Motivation: This deals with those aspects which the organization will have to deal with in order to be able to derive more work from the individual while all other resources remaining constant. This is an organization oriented aspect of work life balance. By providing motivational incentives that enable the employee to provide better output qualitatively and quantitatively, the organization sows the seeds of ever increasing productivity among its work force.

3.3 Job Satisfaction: This is an important feedback mechanism which the employee gains in terms of the personal, impersonal and intra-personal aspects. Being able to accurately measure, monitor and manipulate this parameter is the alchemical potion for any organization. No matter what the organization does, the employee individually and the group of employees collectively will have to feel that the organizational activities will provide them the same benefits as they claim to be.

3.4 Quality of Work: Different cultures adopt different metrics to measure work qualitatively. With the abilities that the employee is endowed with, the organization would like to ensure that the employee performs the assigned tasks in accordance with the criteria set by them for quality of work. The employee however feels that he/she might be performing to the best of his/her ability. There will now exist a mismatch between the organizational and employee perception of the definition of acceptable quality of work.

3.5 Working Conditions: It is the responsibility of the organization to provide appropriate facilities and mechanisms which enable, enrich and encourage the individuals to perform to the best of their ability. It is the prerogative of the organization to ensure that appropriate mechanisms are available which act as a feedback mechanism for modifying the working conditions so that they become conducive to a healthy work culture.

3.6 Quality of Work-Life Balance: The main aim of this study is to arrive at parameters which could accurately represent the parameters affecting work life balance. Once these parameters are identified, mechanisms could be designed which can indicate the possible intrusions of work aspects gaining a prominence into life aspects or life aspects gaining an edge over work aspects.

IV. Suggested Methodology for stress representation using Six Dimensional Model

4.1 Survey: A survey was carried out using a questionnaire in the hospitals in Visakhapatnam by considering 219 samples. The main aim of the survey was to gather information about the physical, social and psychological stress faced by health care professionals in Visakhapatnam.

\subsection{Statistical Analysis Reliability:}

Table 1: Reliability Statistics

\begin{tabular}{|c|c|}
\hline Cronbach's Alpha & N of Items \\
\hline 0.845 & 21 \\
\hline
\end{tabular}

Table 2: Scale Statistics

\begin{tabular}{|c|c|c|c|}
\hline Mean & Variance & Std. Deviation & N of Items \\
\hline 73.02 & 126.658 & 11.254 & 21 \\
\hline
\end{tabular}

Inference: Cronbach's alpha has been run for to check their reliability. The overall alpha for the all items is 0.845 , which is very high and indicates strong internal consistency among the given items.

$\mathrm{H}_{0} 1$ : There is no significant association between organization type and their opinions on comfortable with occupational duty timing

\begin{tabular}{|c|c|c|c|c|c|c|c|c|}
\hline & & & $\frac{1}{1}$ & $\frac{1}{2}$ & 3 & 4 & 5 & Total \\
\hline \multirow{5}{*}{ Organization type } & \multirow[t]{2}{*}{ Corporate } & Count & 11 & 12 & 11 & 52 & 11 & 97 \\
\hline & & $\%$ & $11.3 \%$ & $12.4 \%$ & $11.3 \%$ & $53.6 \%$ & $11.3 \%$ & $100.0 \%$ \\
\hline & \multirow[t]{2}{*}{ Government } & Count & 4 & 11 & 13 & 48 & 13 & 89 \\
\hline & & $\%$ & $4.5 \%$ & $12.4 \%$ & $14.6 \%$ & $53.9 \%$ & $14.6 \%$ & $100.0 \%$ \\
\hline & Private nursing & Count & 0 & 3 & 5 & 19 & 6 & 33 \\
\hline
\end{tabular}


A Six Dimensional Model for Understanding the Stress faced by Health Care Professionals working

\begin{tabular}{|l|l|c|l|l|l|l|l|}
\hline & $\%$ & $0.0 \%$ & $9.1 \%$ & $15.2 \%$ & $57.6 \%$ & $18.2 \%$ & $100.0 \%$ \\
\hline \multirow{2}{*}{ Total } & Count & 15 & 26 & 29 & 119 & 30 & 219 \\
\cline { 2 - 8 } & $\%$ & $6.8 \%$ & $11.9 \%$ & $13.2 \%$ & $54.3 \%$ & $13.7 \%$ & $100.0 \%$ \\
\hline
\end{tabular}

\begin{tabular}{|l|c|c|c|}
\hline \multicolumn{5}{|c|}{ Table 4. Chi-Square Test for above survey } \\
\hline Pearson Chi-Square & $7.579^{\mathrm{a}}$ & 8 & .476 \\
\hline Likelihood Ratio & 9.465 & 8 & .305 \\
\hline N of Valid Cases & 219 & & \\
\hline
\end{tabular}

a. 4 cells $(26.7 \%)$ have expected count less than 5 . The minimum expected count is 2.26 .

From the above table chi square is not significant (sig. value is $>0.05$ ), no evidence to reject null hypothesis. It means that there is no significant association between organization type and their opinions on comfortable with occupational duty timings.

No dependency between the type of organization in which the employee works and the opinions that these employees have with respect to the comfort that they feel with their occupational timings. The medical profession is one which lays a lot emphasis on timely intervention and regular monitoring. This demands consequent sacrifices to be made or rather greater commitments being done to the professional front while the personal life is sent to the background. This emphasis on the professional life aspects while disregarding the personal aspects results in physical, psychological stress which negatively impacts performance.

$\mathrm{H}_{0} 2$ : There is no significant association between organization type and their opinions on could able to generate regular income

\begin{tabular}{|c|c|c|c|c|c|c|c|c|}
\hline \multicolumn{9}{|c|}{ Table 5. Ability to generate regular monthly income } \\
\hline & & & 1 & 2 & 3 & 4 & 5 & Total \\
\hline \multirow{6}{*}{$\begin{array}{l}\text { Organization } \\
\text { type }\end{array}$} & \multirow[t]{2}{*}{ Corporate } & Count & 4 & 12 & 20 & 48 & 13 & 97 \\
\hline & & $\%$ & $4.1 \%$ & $12.4 \%$ & $20.6 \%$ & $49.5 \%$ & $13.4 \%$ & $100.0 \%$ \\
\hline & \multirow[t]{2}{*}{ Government } & Count & 3 & 9 & 20 & 45 & 12 & 89 \\
\hline & & $\%$ & $3.4 \%$ & $10.1 \%$ & $22.5 \%$ & $50.6 \%$ & $13.5 \%$ & $100.0 \%$ \\
\hline & \multirow[t]{2}{*}{ Private nursing } & Count & 0 & 2 & 9 & 17 & 5 & 33 \\
\hline & & $\%$ & $0.0 \%$ & $6.1 \%$ & $27.3 \%$ & $51.5 \%$ & $15.2 \%$ & $100.0 \%$ \\
\hline & \multirow{2}{*}{ Total } & Count & 7 & 23 & 49 & 110 & 30 & 219 \\
\hline & & $\%$ & $3.2 \%$ & $10.5 \%$ & $22.4 \%$ & $50.2 \%$ & $13.7 \%$ & $100.0 \%$ \\
\hline
\end{tabular}

\begin{tabular}{|l|c|c|c|}
\hline \multicolumn{5}{|c|}{ Table 6. Chi-Square Test for above survey } \\
\hline Pearson Chi-Square & $2.851^{\mathrm{a}}$ & 8 & .943 \\
\hline Likelihood Ratio & 3.957 & 8 & .861 \\
\hline N of Valid Cases & 219 & & \\
\hline
\end{tabular}

a. 5 cells $(33.3 \%)$ have expected count less than 5 . The minimum expected count is 1.05 .

From the above table chi square is not significant (sig. value is $>0.05$ ), no evidence to reject null hypothesis. It means that there is no significant association between organization type and their opinions on could able to generate regular income.

No dependency between the type of organization in which the employee works and the opinions that these employees have with respect to the ability to generate regular income. In the Indian context the medical profession is considered to be a noble profession where the intellectual elite pursue. There is always a wide gap between the supply and demand of qualified medical professionals taking into consideration the demands of the ever increasing population. This results in the demand for qualified medical professionals who will have to undergo their professional work days while compromising their personal lives. As a result the reduced supply and increasing demand implies that the medical professionals are compensated satisfactorily as the result indicates.

$\mathrm{H}_{0} 3$ : There is no significant association between organization type and their opinions on able to perform job satisfaction.

\begin{tabular}{|c|l|l|l|l|l|l|l|l|l|}
\hline \multicolumn{9}{|c|}{ Table 7. Ability to perform job to my complete satisfaction } & \multicolumn{1}{|c|}{ Total } \\
\hline \multirow{3}{*}{$\begin{array}{c}\text { Organization } \\
\text { type }\end{array}$} & Corporate & Count & 7 & 10 & 14 & 52 & 14 & 97 \\
\cline { 2 - 10 } & Government & $\%$ & $7.2 \%$ & $10.3 \%$ & $14.4 \%$ & $53.6 \%$ & $14.4 \%$ & $100.0 \%$ \\
\hline
\end{tabular}




\begin{tabular}{|c|l|c|l|l|l|l|l|l|}
\hline & & $\%$ & $5.6 \%$ & $7.9 \%$ & $14.6 \%$ & $49.4 \%$ & $22.5 \%$ & $100.0 \%$ \\
\cline { 2 - 8 } & Private nursing & Count & 0 & 0 & 13 & 10 & 10 & 33 \\
\cline { 3 - 9 } & $\%$ & $0.0 \%$ & $0.0 \%$ & $39.4 \%$ & $30.3 \%$ & $30.3 \%$ & $100.0 \%$ \\
\hline \multirow{2}{*}{ Total } & Count & 12 & 17 & 40 & 106 & 44 & 219 \\
\cline { 2 - 8 } & $\%$ & $5.5 \%$ & $7.8 \%$ & $18.3 \%$ & $48.4 \%$ & $20.1 \%$ & $100.0 \%$ \\
\hline
\end{tabular}

\begin{tabular}{|l|c|c|c|}
\hline \multicolumn{5}{|c|}{ Table 8 Chi-Square Test for above survey } \\
\hline Pearson Chi-Square & $21.523^{\mathrm{a}}$ & 8 & .006 \\
\hline Likelihood Ratio & 24.104 & 8 & .002 \\
\hline N of Valid Cases & 219 & & \\
\hline
\end{tabular}

a. 3 cells $(20 \%)$ have expected count less than 5 . The minimum expected count is 1.81 .

From the above table chi square is significant (sig. value is $<0.05$ ), reject null hypothesis. It means that there is a significant association between organization type and their opinions on able to perform job satisfaction $\mathrm{H}_{0} 4$ : There is no significant association between organization type and their opinions on able to perform job to the satisfaction of management.

\begin{tabular}{|c|c|c|c|c|c|c|c|c|}
\hline & & & 1 & 2 & 3 & 4 & 5 & Total \\
\hline \multirow{4}{*}{$\begin{array}{l}\text { Organization } \\
\text { type }\end{array}$} & Corporate & Count & 2 & 9 & 21 & 43 & 22 & 97 \\
\hline & \multirow[t]{2}{*}{ Government } & Count & 6 & 4 & 22 & 46 & 11 & 89 \\
\hline & & $\%$ & $6.7 \%$ & $4.5 \%$ & $24.7 \%$ & $51.7 \%$ & $12.4 \%$ & $100.0 \%$ \\
\hline & Private nursing & $\%$ & $0.0 \%$ & $3.0 \%$ & $18.2 \%$ & $60.6 \%$ & $18.2 \%$ & $100.0 \%$ \\
\hline & \multirow{2}{*}{ total } & Count & 8 & 14 & 49 & 109 & 39 & 219 \\
\hline & & $\%$ & $3.7 \%$ & $6.4 \%$ & $22.4 \%$ & $49.8 \%$ & $17.8 \%$ & $100.0 \%$ \\
\hline
\end{tabular}

\begin{tabular}{|l|c|c|c|}
\hline \multicolumn{5}{|c|}{ Table 10. Chi-Square Test for above survey } \\
\hline Pearson Chi-Square & $11.252^{\mathrm{a}}$ & 8 & .188 \\
\hline Likelihood Ratio & 12.217 & 8 & .142 \\
\hline N of Valid Cases & 219 & & \\
\hline
\end{tabular}

a. 4 cells $(26.7 \%)$ have expected count less than 5 . The minimum expected count is 1.21

From the above table chi square is not significant (sig. value is $>0.05$ ), no evidence to reject null hypothesis. It means that there is no significant association between organization type and their opinions on able to perform job to the satisfaction of management

There are two aspects of job satisfaction, one which the employee feels with respect to being able to perform to his/her own ability and the second which the employee feels with respect to being able to perform the job to the satisfaction of the management. As the results indicate both these aspects are independent of the type of organization. This means that the employees, independent of the type of organization feel that they are able to perform the job to their own satisfaction as well as to the satisfaction of the management. An employee who feels that he/she exceeds his/her own expectations as well as those of the organization will not be subjected to any stress caused due to performance gap. As the gap between the actual and expected performance increases the employee experiences more amounts of stress which further reduces performance. This cycle of reduced performance causing stress and stress further reducing the performance if not checked will be detrimental to the performance of the organization itself. Thus it is the responsibility of the managements to identify the causative factors and take appropriate measures to mitigate it.

$\mathrm{H}_{0} 5$ : There is no significant association between organization type and their opinions on knowledge oriented discussion with my colleagues

\begin{tabular}{|c|c|c|c|c|c|c|c|c|}
\hline & $\mathrm{Tab}$ & to have & ge orie & & alt & & & \\
\hline & & & 1 & 2 & 3 & 4 & 5 & Total \\
\hline \multirow{5}{*}{$\begin{array}{l}\text { Organization } \\
\text { type }\end{array}$} & \multirow[t]{2}{*}{ Corporate } & Count & 5 & 6 & 20 & 50 & 16 & 97 \\
\hline & & $\%$ & $5.2 \%$ & $6.2 \%$ & $20.6 \%$ & $51.5 \%$ & $16.5 \%$ & $100.0 \%$ \\
\hline & \multirow[t]{2}{*}{ Government } & Count & 4 & 2 & 13 & 56 & 14 & 89 \\
\hline & & $\%$ & $4.5 \%$ & $2.2 \%$ & $14.6 \%$ & $62.9 \%$ & $15.7 \%$ & $100.0 \%$ \\
\hline & Private nursing & Count & 0 & 1 & 6 & 17 & 9 & 33 \\
\hline
\end{tabular}


A Six Dimensional Model for Understanding the Stress faced by Health Care Professionals working

\begin{tabular}{|l|l|l|l|l|l|l|l|l|}
\hline & & $\%$ & $0.0 \%$ & $3.0 \%$ & $18.2 \%$ & $51.5 \%$ & $27.3 \%$ & $100.0 \%$ \\
\hline \multirow{2}{*}{ total } & Count & 9 & 9 & 39 & 123 & 39 & 219 \\
\cline { 2 - 8 } & $\%$ & $4.1 \%$ & $4.1 \%$ & $17.8 \%$ & $56.2 \%$ & $17.8 \%$ & $100.0 \%$ \\
\hline
\end{tabular}

\begin{tabular}{|l|c|c|c|}
\hline \multicolumn{4}{|c|}{ Table 12. Chi-Square Test for above survey } \\
\hline Pearson Chi-Square & $7.641^{\mathrm{a}}$ & 8 & .469 \\
\hline Likelihood Ratio & 8.775 & 8 & .342 \\
\hline N of Valid Cases & 219 & & \\
\hline
\end{tabular}

a. 46cells $(40 \%)$ have expected count less than 5 . The minimum expected count is 1.36

From the above table chi square is not significant (sig. value is $>0.05$ ), no evidence to reject null hypothesis. It means that there is no significant association between organization type and their opinions on knowledge oriented discussion with my colleagues

$\mathrm{H}_{0} 6$ : There is no significant association between organization type and their opinions on able to spend time with family

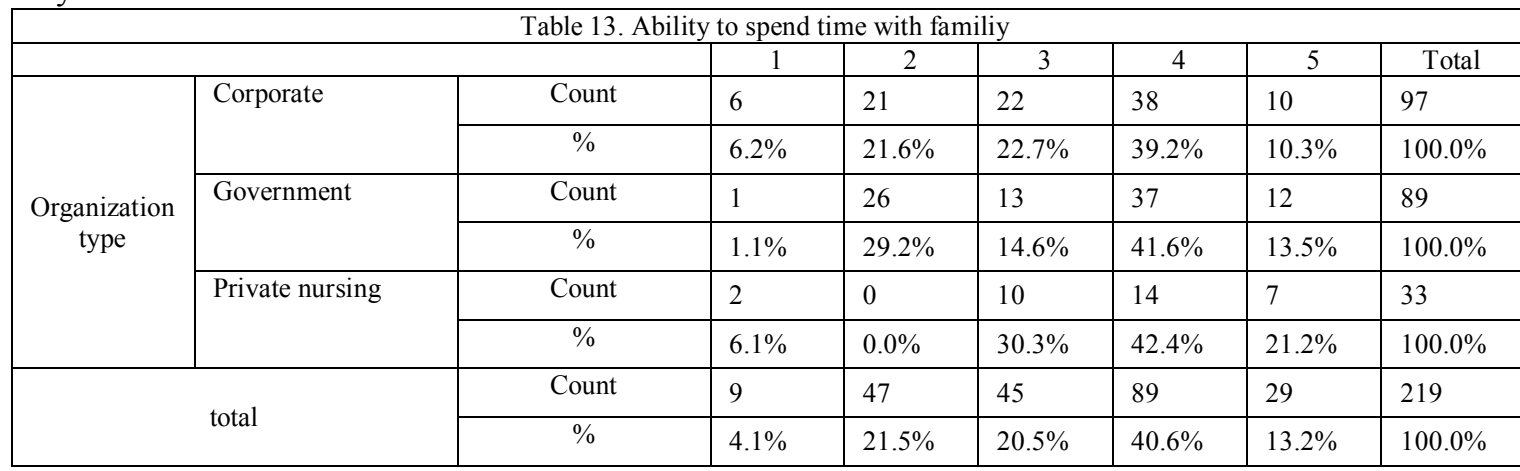

\begin{tabular}{|l|c|c|c|}
\hline \multicolumn{4}{|c|}{ Table 14. Chi-Square Test for above survey } \\
\hline Pearson Chi-Square & $7.579^{\mathrm{a}}$ & 8 & .476 \\
\hline Likelihood Ratio & 9.465 & 8 & .305 \\
\hline N of Valid Cases & 219 & & \\
\hline
\end{tabular}

a. 4 cells $(26.7 \%)$ have expected count less than 5 . The minimum expected count is 2.26 .

From the above table chi square is significant (sig. value is $<0.05$ ), reject null hypothesis. It means that there is a significant association between organization type and their opinions on able to spend time with family $\mathrm{H}_{0}$ 7: There is no significant association between organization type and their opinions on able to spare time for parents, elders in family

\begin{tabular}{|c|c|c|c|c|c|c|c|c|}
\hline \multicolumn{9}{|c|}{ Table 15 . Ability to spend time for family members } \\
\hline & & & 1 & 2 & 3 & 4 & 5 & Total \\
\hline \multirow{6}{*}{ Organization type } & \multirow{2}{*}{ Corporate } & Count & 6 & 22 & 21 & 36 & 12 & 97 \\
\hline & & $\%$ & $6.2 \%$ & $22.7 \%$ & $21.6 \%$ & $37.1 \%$ & $12.4 \%$ & $100.0 \%$ \\
\hline & \multirow[t]{2}{*}{ Government } & Count & 11 & 13 & 17 & 41 & 7 & 89 \\
\hline & & $\%$ & $12.4 \%$ & $14.6 \%$ & $19.1 \%$ & $46.1 \%$ & $7.9 \%$ & $100.0 \%$ \\
\hline & \multirow[t]{2}{*}{ Private nursing } & Count & 1 & 2 & 10 & 12 & 8 & 33 \\
\hline & & $\%$ & $3.0 \%$ & $6.1 \%$ & $30.3 \%$ & $36.4 \%$ & $24.2 \%$ & $100.0 \%$ \\
\hline \multirow{2}{*}{\multicolumn{2}{|c|}{ total }} & Count & 18 & 37 & 48 & 89 & 27 & 219 \\
\hline & & $\%$ & $8.2 \%$ & $16.9 \%$ & $21.9 \%$ & $40.6 \%$ & $12.3 \%$ & $100.0 \%$ \\
\hline
\end{tabular}

\begin{tabular}{|l|c|c|c|}
\hline \multicolumn{4}{|c|}{ Table 16. Chi-Square Test for above survey } \\
\hline Pearson Chi-Square & $18.415^{\text {a }}$ & 8 & .018 \\
\hline Likelihood Ratio & 25.630 & 8 & .001 \\
\hline N of Valid Cases & 219 & & \\
\hline
\end{tabular}

a. 4 cells $(26.7 \%)$ have expected count less than 5 . The minimum expected count is 1.36 .

From the above table chi square is significant (sig. value is $<0.05$ ), reject null hypothesis. It means that there is a significant association between organization type and their opinions on able to spare time for parents, elders in family

$\mathrm{H}_{0} 8$ : There is no significant association between organization type and their opinions on able to spare time for friends 
A Six Dimensional Model for Understanding the Stress faced by Health Care Professionals working

\begin{tabular}{|c|c|c|c|c|c|c|c|c|}
\hline \multicolumn{9}{|c|}{ Table 17. Ability to spend time for friends } \\
\hline & & & 1 & 2 & 3 & 4 & 5 & Total \\
\hline \multirow{6}{*}{ Organization type } & \multirow[t]{2}{*}{ Corporate } & Count & 7 & 25 & 22 & 36 & 7 & 97 \\
\hline & & $\%$ & $7.2 \%$ & $25.8 \%$ & $22.7 \%$ & $37.1 \%$ & $7.2 \%$ & $100.0 \%$ \\
\hline & \multirow[t]{2}{*}{ Government } & Count & 7 & 13 & 27 & 38 & 4 & 89 \\
\hline & & $\%$ & $7.9 \%$ & $14.6 \%$ & $30.3 \%$ & $42.7 \%$ & $4.5 \%$ & $100.0 \%$ \\
\hline & \multirow[t]{2}{*}{ Private nursing } & Count & 1 & 1 & 7 & 21 & 3 & 33 \\
\hline & & $\%$ & $3.0 \%$ & $3.0 \%$ & $21.2 \%$ & $63.6 \%$ & $9.1 \%$ & $100.0 \%$ \\
\hline \multirow{2}{*}{\multicolumn{2}{|c|}{ total }} & Count & 15 & 39 & 56 & 95 & 14 & 219 \\
\hline & & $\%$ & $6.8 \%$ & $17.8 \%$ & $25.6 \%$ & $43.4 \%$ & $6.4 \%$ & $100.0 \%$ \\
\hline \multicolumn{9}{|c|}{ Table 18. Chi-Square Test for above survey } \\
\hline \multicolumn{2}{|l|}{ Pearson Chi-Square } & $15.628^{\mathrm{a}}$ & \multicolumn{3}{|c|}{8} & \multicolumn{3}{|c|}{.048} \\
\hline \multicolumn{2}{|l|}{ Likelihood Ratio } & 15.612 & \multicolumn{3}{|c|}{8} & \multicolumn{3}{|c|}{.048} \\
\hline \multicolumn{2}{|l|}{$\mathrm{N}$ of Valid Cases } & 219 & & \\
\hline
\end{tabular}

a. 4 cells $(26.7 \%)$ have expected count less than 5 . The minimum expected count is 1.36 .

From the above table chi square is significant ( $\mathrm{sig}$. value is $>=0.05$ ), reject null hypothesis. It means that there is a significant association between organization type and their opinions on able to spare time for friends.

$\mathrm{H}_{0} 9$ : There is no significant association between organization type and their opinions on professional work is often disturbs personal life

\begin{tabular}{|c|c|c|c|c|c|c|c|c|}
\hline \multicolumn{9}{|c|}{ Table 19. Professional work disturbs family life } \\
\hline & & & 1 & 2 & 3 & 4 & 5 & Total \\
\hline \multirow{6}{*}{ Organization type } & \multirow[t]{2}{*}{ Corporate } & Count & 4 & 17 & 21 & 40 & 15 & 97 \\
\hline & & $\%$ & $4.1 \%$ & $17.5 \%$ & $21.6 \%$ & $41.2 \%$ & $15.5 \%$ & $100.0 \%$ \\
\hline & \multirow[t]{2}{*}{ Government } & Count & 5 & 19 & 22 & 35 & 7 & 88 \\
\hline & & $\%$ & $5.7 \%$ & $21.6 \%$ & $25.0 \%$ & $39.8 \%$ & $8.0 \%$ & $100.0 \%$ \\
\hline & \multirow[t]{2}{*}{ Private nursing } & Count & 0 & 5 & 10 & 15 & 3 & 33 \\
\hline & & $\%$ & $0.0 \%$ & $15.2 \%$ & $30.3 \%$ & $45.5 \%$ & $9.1 \%$ & $100.0 \%$ \\
\hline \multirow{2}{*}{\multicolumn{2}{|c|}{ total }} & Count & 9 & 41 & 53 & 90 & 25 & 218 \\
\hline & & $\%$ & $4.1 \%$ & $18.8 \%$ & $24.3 \%$ & $41.3 \%$ & $11.5 \%$ & $100.0 \%$ \\
\hline
\end{tabular}

\begin{tabular}{|l|c|c|c|}
\hline \multicolumn{3}{|c|}{ Table 20. Chi-Square Test for above survey } & .685 \\
\hline Pearson Chi-Square & $5.662^{\mathrm{a}}$ & 8 & .550 \\
\hline Likelihood Ratio & 6.879 & 8 & \\
\hline N of Valid Cases & 219 & & \\
\hline
\end{tabular}

a. 5 cells $(33.3 \%)$ have expected count less than 5 . The minimum expected count is 1.36

From the above table chi square is significant ( $\mathrm{sig}$. value is $>0.05$ ), no evidence to reject null hypothesis. It, $\mathrm{k} . / / /$ means that there is no significant association between organization type and their opinions on professional work is often disturbs personal life

$\mathrm{H}_{0} 10$ : There is no significant association between organization type and their opinions on accompany of family to professional visit

\begin{tabular}{|c|c|c|c|c|c|c|c|c|}
\hline \multicolumn{9}{|c|}{ Table 21. Possibility of accompanying family on Professional visit } \\
\hline & & & 1 & 2 & 3 & 4 & 5 & Total \\
\hline \multirow{6}{*}{$\begin{array}{l}\text { Organization } \\
\text { type }\end{array}$} & \multirow[t]{2}{*}{ Corporate } & Count & 5 & 11 & 20 & 54 & 7 & 97 \\
\hline & & $\%$ & $5.2 \%$ & $11.3 \%$ & $20.6 \%$ & $55.7 \%$ & $7.2 \%$ & $100.0 \%$ \\
\hline & \multirow[t]{2}{*}{ Government } & Count & 4 & 15 & 21 & 40 & 9 & 89 \\
\hline & & $\%$ & $4.5 \%$ & $16.9 \%$ & $23.6 \%$ & $44.9 \%$ & $10.1 \%$ & $100.0 \%$ \\
\hline & \multirow[t]{2}{*}{ Private nursing } & Count & 0 & 4 & 7 & 17 & 5 & 33 \\
\hline & & $\%$ & $0.0 \%$ & $12.1 \%$ & $21.2 \%$ & $51.5 \%$ & $15.2 \%$ & $100.0 \%$ \\
\hline \multirow{2}{*}{\multicolumn{2}{|c|}{ total }} & Count & 9 & 30 & 48 & 111 & 21 & 219 \\
\hline & & $\%$ & $4.1 \%$ & $13.7 \%$ & $21.9 \%$ & $50.7 \%$ & $9.6 \%$ & $100.0 \%$ \\
\hline
\end{tabular}




\begin{tabular}{|l|c|c|c|}
\hline \multicolumn{5}{|c|}{ Table 22. Chi-Square Test for above survey } \\
\hline Pearson Chi-Square & $5.662^{\mathrm{a}}$ & 8 & .685 \\
\hline Likelihood Ratio & 6.879 & 8 & .550 \\
\hline N of Valid Cases & 219 & & \\
\hline
\end{tabular}

a. 5 cells $(33.3 \%)$ have expected count less than 5 . The minimum expected count is 1.36 .

From the above table chi square is not significant (sig. value is $>0.05$ ), no evidence to reject null hypothesis. It means that there is no significant association between organization type and their opinions on accompany of family to professional visit.

\section{Results}

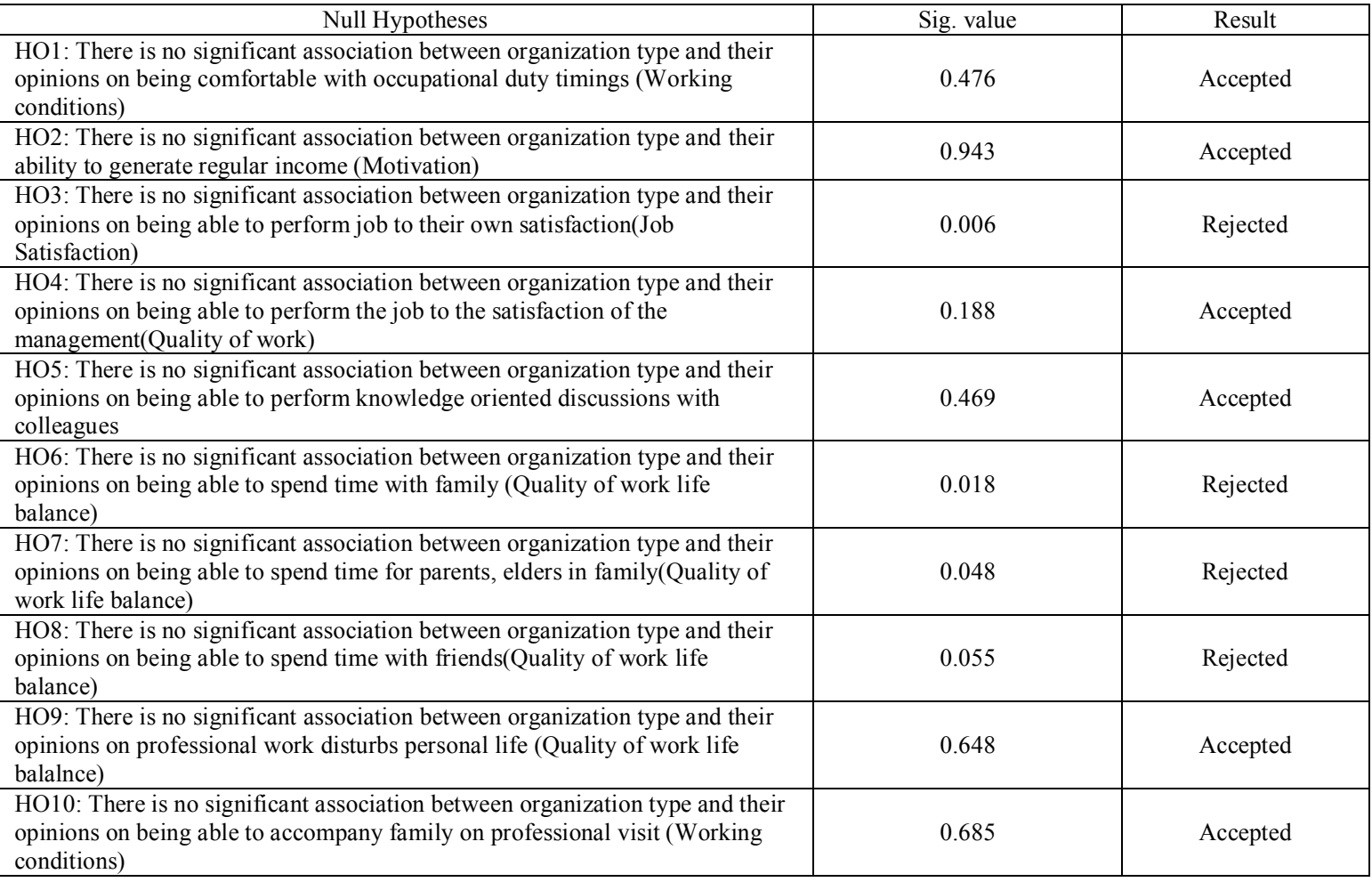

The above results indicate that:

5.1. Irrespective of the type of organization, Health Care Professionals (HCP) feel that they are comfortable with their job timings. This indicates that the health care industry in Visakhapatnam to a significant extent provides its employees with job timings which are convenient. This implies that although inconvenient work timings are a cause of stress, which is not the major reason for the cause of stress which may be faced by them. This indicates that the Working conditions in Health care organizations in Visakhapatnam is satisfactory.

5.2. The second result indicates that all Health care professionals in Visakhapatnam, irrespective of the type of organization to which they belong to feel that they are able to generate regular income. This is a welcome situation because anxiety about a regular income is generally considered to be a major cause of stress; but the situation here indicates one which can be appreciated. This indicates that Health care organizations are taking proper care about creating and providing adequate salaries to their employees. Therefore, this cannot be a major cause of stress and therefore work-life imbalance as the required Motivation in terms of monetary benefits is available.

5.3. This result indicates a possible disparity among the various HCP's working in various types of organizations regarding their ability to perform the job to their satisfaction. Thus employees working in one type of organization may feel that they are able to perform their job to their own satisfaction to an extent which matches their skill and ability, which may not be the case with employees of another type of organization. Thus organizations will have to ensure that these differences where ever they exist are identified and appropriate measures taken to reduce them so that the problem of job satisfaction is taken care of appropriately.

5.4. Contrary to the previous result, the current result indicates that the HCP's feel that they are all able to perform their jobs to the fulfillment of organizational objectives in which they are working. This however indicates the perception of the HCP and not of the organization.

Results given in 3 and 4 above show the contrarian nature of human nature. On the one hand HCP's feel that are fulfilling organizational objectives, while on the other hand feel that they are not able to perform the job to the 
best of their skills and abilities. This indicates a difference in their perspective of expected performance from organization (which they are able to fulfill) and the expected performance from the self (which they are unable to fulfill). This difference may result in performance anxiety which causes stress. This also indicates that no matter how good the working conditions are designed at the work place to suit the fulfillment of organizational objectives, there is still the possibility of them not being able to match individual needs.

5.5. This result indicates a positive trend that all health care organizations in Visakhapatnam do provide mechanisms which allow sharing of knowledge, experiences, latest trends and best practices among their HCP's.

5.6. The next three results indicates that HCP's working different types of Health care organizations in Visakhapatnam feel the absence of unanimity among HCP's working in Visakhapatnam to be able to spend time with their immediate family, their parents and elder members and finally their friends. So HCP's working in a particular type of organization may be able to spend time while the others working in a different type of organization may not be able to spend the same amount of time. Spending time with family is a cause of great personal satisfaction. Thus those types of organizations which are unable to provide this incentive to the HCP will have to create appropriate measures for this purpose.

5.7. The next result indicates that all HCP's feel that their Professional work interferes with their personal life. This is a major indicator of the Work - Life imbalance prevalent in the Health care organizations in Visakhapatnam and therefore the relevance of this study.

5.8. The final result deals with the benefits that accrue with working in the medical profession such as family members being able to accompany the HCP's on their professional visits such as to conferences etc., This indicates a positive trend as this allows the HCP to be motivated (as the family member is being benefited along with them) and the organization to achieve the resultant increased productivity.

\section{Conclusions}

This paper tried to provide a mechanism to identify the stress factors which are mostly hidden to a large extent behind the benefits that a job provides. These hidden stress factors which if left unchecked might slowly develop from a small breeze to a mighty hurricane. Therefore, incorporating appropriate mechanisms which can identify these stress factors on a continuous basis, and using appropriate methods to reduce it to acceptable levels is the main task faced by organization. In this direction, surveys were conducted, data gathered and statistically analyzed and a six dimensional model proposed which aims at understanding stress and the resultant work life imbalance. Stress reduces productivity, a stressed out employee is a liability both to himself/herself and to the organization. So organizations will have to focus on reducing stress to firstly maintain and later on improve performance.

\section{References}

[1] Jan Ole Rovik*, Reidar Tyssen, Erlend Hem, Tore Gude, Øivind Ekeberg, Torbjørn Moum and Per Vaglum (2007), “Job Stress in Young Physicians with an Emphasis on the Work-Home Interface: A Nine-Year, Nationwide and Longitudinal Study of its Course and Predictors" Industrial Health, 45, 662-671.

[2 ]Ariel C. Avgar, Rebecca Kolins Givan and Mingwei Liu(2011), “A Balancing Act:Work-Life Balance and Multiple stakeholder Outcomes in Hospitals”, British Journal of Industrial Relations doi: 10.1111/j.1467-8543.2010.00839.x 49:4 December 2011 00071080 pp. $717-741$

[3] Beauregard, T. A. and Henry, L. C. (2009). 'Making the link between work-life balance practices and organizational performance'. Human Resource ManagementReview, 19: 9-22.

[4] Frame P and Hartog M (2003), "FromRhetoric to Reality, into the Swamp of Ethical Practice: Implementing Work-Life Balance", Business Ethics:A European Review, Vol. 12 No. 4, pp. 358-367.

[5] Obstet Gynecol (2007), "Physician Work-Life Balance and Burnout", American college of Obstetrician and Gynecologists, VOL. 109, NO. 4, APRIL 2007, 949-55.

[6] Phil J.M. Heiligers ${ }^{\mathrm{a}, \mathrm{b},{ }^{*}, \text { L. Hingstman }}{ }^{\mathrm{a}}$, "Career preferences and the work family balance in medicine: gender differences among medical specialists", Social Science \& Medicine 50 (2000), 1235 \pm 1246

[7] Sue Campbell Clark, July 2010, "WORK/FAMILY BORDER Theory: A new theory of Work/family Balance", HUMAN RELATIONS 2000, 53:747 -770.

[8] Wise, S. (2003). 'Reconciling career and family life in NHS nursing and midwifery: dilemmas in ward management'. In Dilemmas in Human Services 7th International ResearchConference, Staffordshire University, http://researchrepository.napier.ac.uk/2411/

M.Satyavathi. A Post Graduate in Business Administration from Andhra University, she is presently a Research Scholar at JNTU KAKINADA. Her research interests include various aspects of Work- Life Balance and Imbalances among the Medical Health Professionals in general and to those working in Visakhapatnam in particular. She has presented papers at various conferences in India.

Dr.P.Vijaya Kumar. A Professor of Commerce \& Director of School of Management Studies, JNTU Kakinada. His specializations include Human Resource Management, Management Accountancy and Cost Accountancy. He has published a large number of Research Papers in various Journals of repute. He has presented papers at various National and International Conferences. 